\title{
Interphase ribosomal RNA cistron staining in chronic myeloid leukaemia
}

\section{Department of Haematology and Cytogenetic Unit, Faculty Therapy Clinic, \\ Pavlov Medical University of St Petersburg, Leo Tolstoy Street 6/8, St Petersburg 197089, Russia \\ N N Mamaev G N Salogub A V Koloskov \\ Correspondence to: Dr Nikolai Mamaev.}

\author{
N N Mamaev, G N Salogub, A V Koloskov
}

\begin{abstract}
Aim-To evaluate the haemopoietic function of bone marrow blood forming cells in human chronic myeloid leukaemia (CML) by means of silver staining of nucleolar organiser region (AgNOR).

Methods-Nucleoli were investigated in bone marrow blast cells and in erythroid, granulocytic, and megakaryocytic cells from 10 haematologically healthy subjects and from 26 patients with chronic myeloid leukemia (17 in benign phase, nine with blast crisis). The investigation was done before treatment, by means of a one step silver staining method. In every case 50 to 100 blasts, promyelocytes, myelocytes, immature (pronormoblastic and basophilic normoblastic) and mature (polychromatic normoblastic) erythroid elements, and megakaryocytes were evaluated for the mean numbers of nucleoli and for the average number of AgNORs per nucleus. Student's $t$ test was used to compare the patient and control groups. Other statistical analyses were carried out by means of the computer assisted "HEMA" system.
\end{abstract}

Results-Compared with controls, activation of NORs was noticed only in CML blasts, while there was a decrease in NORs in the erythroid elements, promyelocytes, and megakaryocytes. The AgNOR score of polychromatic normoblasts and megakaryocytes started to decrease in the benign stage of CML, whereas a similar decrease in pronormoblasts, basophilic normoblasts, and promyelocytes was detected only in patients with CML blast crisis.

Conclusions-The loss of AgNOR sites in cell series in CML may be related to intrinsic defects in their proliferation.

(f Clin Pathol: Mol Pathol 1995;48:M260-M263)

Methodological approaches to understanding proliferation in haematopoiesis have recently undergone radical change. Instead of time consuming and expensive autoradiographic and cytophotometric techniques, more elegant quantitative flow cytometric, immunocytochemical, molecular biological, and other approaches have been used. The method of selective nucleolar organiser region silver staining (AgNOR) is of particular interest since it makes it possible to evaluate ribosomal cistron activity (RCA) quantitatively and directly in cytological and histological specimens. ${ }^{1-28}$

The first studies of nucleolar argyrophilia in haematopoietic cells were carried out by
Gonzalez-Guzman ${ }^{910}$ at a time when the exact number of chromosomes and the location of ribosomal genes were not known. He found that AgNOR scores of bone marrow erythroid and granulocytic elements from healthy subjects and from patients with chronic myeloid leukaemia (CML) was diminished with increasing cell differentiation and maturation. According to Gonzalez-Guzman, AgNOR scores were maximal in blast cells, pronormoblasts, and promyelocytes, intermediate in polychromatic normoblasts, myelocytes, and lymphocytes, and minimal in banded cells and neutrophils.

The results of our recent studies ${ }^{71-14}$ are in close agreement with the above data. However, there are intrinsic defects in the haematopoietic function of erythroid, megakaryocytic, and granulocytic elements in CML patients, which has given rise to the present study.

\section{Methods}

The investigation was performed on 26 untreated adult patients with CML (17 in "benign" phase and nine blast crisis phase) who were admitted to the Department of Haematology, Faculty Therapy Clinic, Pavlov Medical University of St Petersburg, Russia.

CML was diagnosed from typical clinical and haematological signs and from cytochemical (alkaline phosphatase) and cytogenetic findings. The typical $\mathrm{Ph}$ chromosome with standard translocation $t(9 ; 22)$ ( $\mathrm{q} 34 ; \mathrm{q} 11)$ was detected in 23 patients. Two cases were $\mathrm{Ph}$-negative and one had no chromosome data. Additional chromosomal anomalies included variant $\mathrm{Ph}$ anomaly (one patient), trisomy 8 or 21 (two patients) and other chromosome abnormalities (one patient). Ten haematologically healthy subjects were used as controls.

Bone marrow smears taken by sternal puncture were air dried, fixed in methanol-glacial acetic acid mixture (3:1) and thoroughly rinsed with distilled water. After repeated air drying the preparations were put into $2 \mathrm{~N}$ formic acid for $10 \mathrm{~min}$, then rinsed again and impregnated with a mixture of $50 \%$ aqueous solution of silver nitrate with gelatin at $68^{\circ} \mathrm{C}$ for $4 \mathrm{~min}$ (after Howell and Black $^{1}$ with slight modification $\left.^{11}\right)$. The preparations were then counterstained with Giemsa (Merck) for $20 \mathrm{~s}$.

In every case, 50-100 blasts, promyelocytes, myelocytes, erythroid elements of the first (Er-I) and second (Er-II) classes (Er-I, pronormoblasts and basophilic normoblasts; Er-II, polychromatic normoblasts), and megakaryocytes were evaluated for the mean numbers of nucleoli and for the numbers of 
Clinical findings, laboratory tests, and nucleolar silver staining data from patients with different phases of chronic myeloid leukaemia (CML). Values are means (SEM).

\begin{tabular}{|c|c|c|c|c|c|c|c|c|c|c|c|c|c|}
\hline \multirow{3}{*}{$\begin{array}{l}\text { CML } \\
\text { phases }\end{array}$} & \multirow{3}{*}{$\begin{array}{l}\text { Patients } \\
\text { (n) }\end{array}$} & \multirow{3}{*}{$\begin{array}{l}\text { Mean age } \\
\text { (years) }\end{array}$} & \multicolumn{5}{|c|}{ Laboratory tests } & \multicolumn{6}{|c|}{ Nucleolar silver staining data: } \\
\hline & & & \multirow[b]{2}{*}{$H b$} & \multirow[b]{2}{*}{$L$} & \multirow[b]{2}{*}{ Plt } & \multicolumn{2}{|l|}{ Blasts } & \multicolumn{6}{|c|}{ Number of nucleoli (above); AgNORs (below) } \\
\hline & & & & & & $p b$ & $b m$ & $B l$ & $\operatorname{Pr}$ & $M c$ & ErI & ErII & $M g$ \\
\hline Benign & 17 & $52 \cdot 6(3 \cdot 3)$ & $115(6)$ & $173(47)$ & $224(42)$ & $2.5(0.8)$ & $2 \cdot 5(0.4)$ & $\begin{array}{r}2 \cdot 8(0 \cdot 1) \\
16 \cdot 4(2 \cdot 1)\end{array}$ & $\begin{array}{r}3 \cdot 2(0 \cdot 1) \\
14.8(1 \cdot 3)\end{array}$ & $\begin{array}{l}3 \cdot 7(0.1) \\
9 \cdot 1(0.4)\end{array}$ & $\begin{array}{r}3 \cdot 2(0 \cdot 1) \\
21 \cdot 4(4 \cdot 2)\end{array}$ & $\begin{array}{l}3.8(0.1) \\
9 \cdot 6(0.4)\end{array}$ & $\begin{array}{l}17.3(2 \cdot 4) \\
43.9(8 \cdot 8)\end{array}$ \\
\hline $\begin{array}{l}\text { Blast } \\
\text { crisis }\end{array}$ & 9 & $63.8(9)$ & $78(7)$ & $121(33)$ & $85(26)$ & $32(6 \cdot 9)$ & $35(7 \cdot 1)$ & $\begin{array}{r}2.9(0.2) \\
15 \cdot 2(2 \cdot 3)\end{array}$ & $\begin{array}{r}2.7(0.6) \\
11.5(1.4)\end{array}$ & $\begin{array}{l}3.5(0.1) \\
8.6(0.7)\end{array}$ & $\begin{array}{r}3 \cdot 1(0 \cdot 1) \\
13 \cdot 7(2 \cdot 0)\end{array}$ & $\begin{array}{l}3.6(0.1) \\
9 \cdot 8(0.8)\end{array}$ & $\begin{array}{l}14.8(2 \cdot 8) \\
31.8(12 \cdot 6)\end{array}$ \\
\hline
\end{tabular}

$\mathrm{Hb}=$ haemoglobin; $\mathrm{L}=$ leucocytes; $\mathrm{Plt}=$ platelets; $\mathrm{pb}=$ peripheral blood; $\mathrm{bm}=$ bone marrow; $\mathrm{Bl}=$ blasts; $\mathrm{Pr}=$ promyelocytes; $\mathrm{Mc}=$ myelocytes; Er $\mathrm{I}=$ pronormoblasts and basophilic normoblasts; $\mathrm{Er} I \mathrm{II}=$ polychromatic normoblasts; $\mathrm{Mg}=$ megakaryocytes.

AgNORs. The mean numbers of nucleoli and AgNORs per nucleus were calculated for each of the above cellular classes and groups. Student's $t$ test was used to compare the patient and the control groups. Some other statistical analyses, including correlation tests, were carried out by means of the computer assisted "HEMA" system. ${ }^{27} 28$

\section{Results}

Clinical findings and the results of nucleolus silver staining of bone marrow cells from controls and from CML patients are presented in the table and the figure.

NUMBERS OF NUCLEOLI

The smallest number of nucleoli was found in blasts of both controls and chronic phase CML
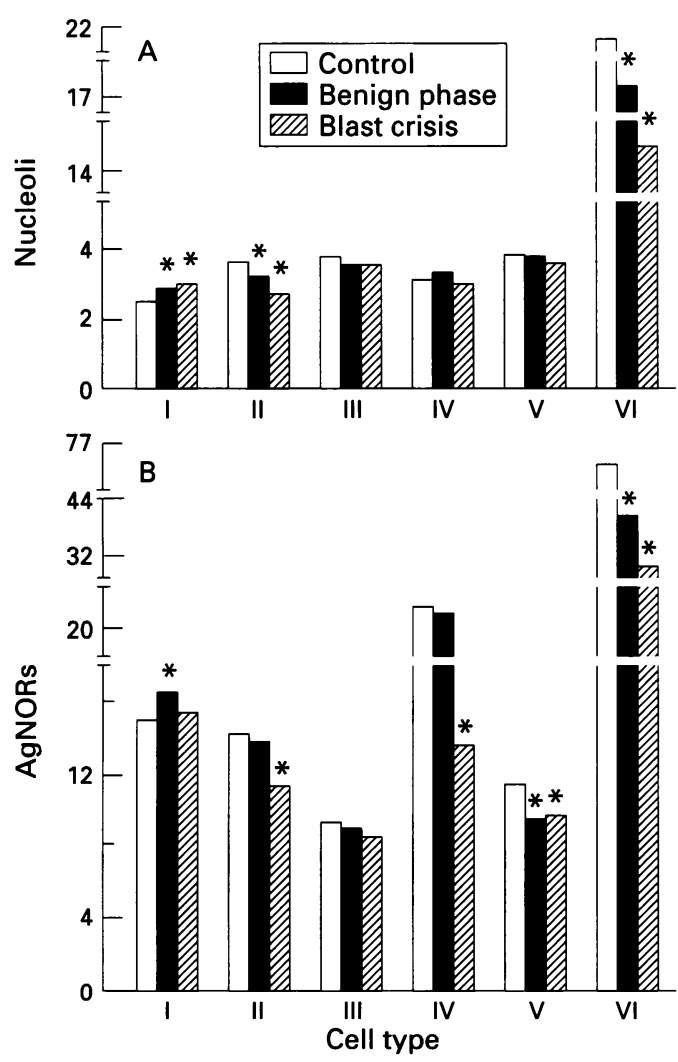

The mean number of nucleoli $(A)$ and the average number of AgNORs (silver stained nucleolar onganiser region) per nucleus (B) in bone marrow blasts (I), promyelocytes (II), myelocytes (III), pronormoblasts and basophilic normoblasts (IV), polychromatic normoblasts (V), and megakaryocytes (VI) from healthy controls and from patients with benign phase and blast crisis $C M L$. $* p<0.05-0.001, C M L v$ control. patients. Numbers were intermediate in promyelocytes, myelocytes, and erythroid elements, and much greater in megakaryocytes. There was a significant difference between the number of nucleoli in leukaemic blasts and that in promyelocytes, myelocytes $(\mathrm{p}<0.001)$, and Er-II $(\mathrm{p}<0.006)$, respectively. The mean number of nucleoli in leukaemic blasts was higher than in controls $(p=0.02)$. On the other hand, it was markedly decreased in leukaemic promyelocytes $(p=0.03)$ and megakaryocytes $(p=$ $0.001)$. It is noteworthy that the mean number of nucleoli in blasts from benign phase CML patients was correlated significantly with the percentage of blasts in bone marrow and with the white blood cell count $(r=0.44, \mathrm{p}<0.006$, and $r=-0.61, \mathrm{p}<0.001$, respectively). The percentage of bone marrow blasts was also inversely associated with the numbers of nucleoli in mature erythroid (Er-II) and granulocytic (myelocyte) elements $(r=-0.64$, $\mathrm{p}<0.001$, and $r=-0.64, \mathrm{p}<0.005, \quad \mathrm{re}-$ spectively).

In patients with CML blast crisis the mean number of nucleoli in blasts also increased, whereas in promyelocytes and megakaryocytes it was diminished compared to the controls. A highly significant correlation was found between the numbers of nucleoli in blasts and the numbers of erythrocytes $(r=0 \cdot 84$; $\mathrm{p}<0.001)$. In contrast to the benign phase of CML, no relationship was observed between blast nucleolus numbers and bone marrow blast content or white blood cell count. The numbers of nucleoli in Er-II were closely related to the white cell count $(r=0.83, \mathrm{p}<0.03)$ and inversely related to the numbers of nucleoli in Er-I $(r=-0 \cdot 81, \mathrm{p}<0 \cdot 02)$.

\section{NUCLEOLAR ARGYROPHILIA OF BONE MARROW} CELLS

In controls and in the patients with the benign stage of $\mathrm{CML}$ the maximum number of $\mathrm{Ag}$ NORs per nucleus was found in megakaryocytes, followed by immature erythroid elements (Er-I). The count was intermediate in blasts, promyelocytes, and Er-II elements, but least in myelocytes. Compared to controls, a statistically significant decrease of AgNOR score was noticed in CML megakaryocytes $(p<0.01)$ and Er-II $(p<0.001)$. The count in blasts correlated closely with that of promyelocytes $(r=0.94, \quad \mathrm{p}<0.001)$, myelocytes $(r=0.83$, $<0.001)$, and Er-I $(r=0.98, \mathrm{p}<0.001)$. Of interest is the fact that the numbers of AgNORs 
in mature erythroid elements were inversely proportional to the percentage of bone marrow blasts $(r=-0.61, \mathrm{p}<0.005)$ and to the white cell count $(r=-0.5, \mathrm{p}<0.03)$. Furthermore, the numbers of AgNORs in nucleoli of promyelocytes $(r=0.37, \mathrm{p}<0.049)$, myelocytes $(r=0.42, \quad \mathrm{p}<0.01), \quad$ and Er-II $\quad(r=0.65$, $\mathrm{p}<0.002)$ showed significant, but weak, correlations with the platelet count.

At CML blast crisis, nucleolar argyrophilia in blasts did not differ from that in controls and in patients in the benign phase of CML. On the other hand, the nucleolar activity of erythroid, granulocytic, and megakaryocytic elements changed greatly. For instance, the nucleolar activity of Er-II in CML patients became lower than in controls, at 8.8 (SEM $0.8) v 11.6(0.4)$ AgNORs per nucleus $(p<0.03)$. A similar but more significant decrease in AgNOR numbers was found in CML Er-I and promyelocytes ( $p<0.001$ and $p<0.01$, respectively).

Additional analysis showed that the AgNOR count in bone marrow blasts of patients in CML blast crisis correlated well with that in promyelocytes $(r=0.79, \mathrm{p}<0.002)$. This cellular feature of Er-I and Er-II elements was closely associated with the numbers of immature erythroid cells in bone marrow $(r=$ $0.89, \mathrm{p}<0.004$, and $r=0.83, \mathrm{p}<0.001$, respectively) and with the percentage of blasts in peripheral blood $(r=0.67, \mathrm{p}<0.03$, and $r=$ $0.87, \mathrm{p}<0.001$ for Er-I and for Er-II populations, respectively). However, there was an opposite interrelationship between the numbers of bone marrow blasts and nucleolar argyrophilia in erythroid precursors $(r=0.79$, $\mathrm{p}<0 \cdot 002)$.

\section{Discussion}

These results show convincingly that, in comparision with controls, some activation of nucleolar organiser regions was noticed in $\mathrm{CML}$ patients only in blasts, while the NOR activity of CML erythroid elements, promyelocytes, and megakaryocytes was decreased. The AgNOR count in polychromatic normoblasts and megakaryocytes started to decrease in the benign stage of CML, whereas a similar decrease was detected in pronormoblasts, basophilic normoblasts, and promyelocytes only on patients with CML blast crisis.

The mean numbers of AgNORs in cells is well known to reflect either their proliferative capacity ${ }^{6-829-31}$ or the degree of nuclear ploidy. ${ }^{1432}$ Review of published reports shows that in CML patients the proliferative potential of immature blasts and of erythroid, granulocytic, and megakaryocytic elements changes in different ways. ${ }^{33-40}$ Proliferative activity of blasts in CML patients in the benign phase does not differ markedly from controls, whereas that of CML promyelocytes, myelocytes, and erythroid precursors in all stages of the disease is slightly but definitely decreased compared to controls. It is therefore not surprising that the general level of rRNA synthesis in CML promyelocytes, myelocytes, and the basic classes of erythroid elements is also dimin- ished. So far as CML megakaryocytes are concerned, it is well known that there is a defect in their ploidy. ${ }^{41}$

Our investigation has shown that the large numbers of nucleoli in benign stage CML blasts correlate closely with the percentage of marrow blasts and with leukocytosis. This implies that CML blasts act aggressively even early in the disease. ${ }^{384243}$ The absence of this correlation in CML blast crisis might partly be explained by increasing accumulation of temporarily nonproliferative (quiescent) blasts in such leukaemic populations. ${ }^{3738}$

The decrease in nucleolar argyrophilia in CML erythroid, granulocytic, and megakaryocytic elements in CML may be related to cellular or humoral feedback mechanisms of haematopoiesis which are triggered by greatly expanded granulocytic and megakaryocytic masses. ${ }^{445}$ The low AgNOR count in proliferating classes of erythroid, granulocytic, and megakaryocytic cells from CML patients is likely to be the result of some intrinsic defects in their proliferative potential. At present, this idea is supported by the following observations. First, megakaryocytes from CML patients are defective in their ability to produce polyploid nuclei and hence to increase their rRNA and protein synthesis. Second, intrinsic defects of CML granulocytes are reflected in a low alkaline phosphatase, low granularity of some polymorphs, and decreased phagocytosis. Third, there are numerous published reports illustrating biochemical ${ }^{46}$ and kinetic disturbances $^{47-49}$ in CML erythroid elements.

1 Howell WM, Black DA. Controlled silver staining of nucleolus organizer regions with a protective colloidal developer: a one step method. Experientia 1980;36:1014-5.

2 Howell WM. Selective staining of nucleolar organizer regions (NORs). In: Bush H, Rothblum L, eds. The cell nucleus, vol XI. New York: Academic Press, 1982:89-142.

3 Scheer U, Hugle B, Hazan R, Rose KM. Drug-induced dispersal of transcribed rRNA-genes and transcriptional products: immunolocalization and silver-staining of different nucleolar components in rat cells treated with 5,6-dichloro- $\beta$-D-ribofuranosylbenzimidazole. $\mathcal{f} \mathrm{Cell} \mathrm{Biol}$ 1984;89:672-9.

4 Ploton D, Menager M, Jeannesson P, Himber G, Pigeon $\mathrm{F}$, Adnet JJ. Improvement in the staining and in the visualization of the argirophilic proteins on the nucleolar organizer region at the optical level. Histochem $\mathcal{F}$ 1986;18: organizer.

5 Crocker J, Nar P. Nucleolar organizer regions in lymphomas. f Pathol 1987;151:111-8.

6 Crocker J. Nucleolar organizer regions. Curr Top Pathol 1990;82:91-149.

7 Mamaev N, Mamaeva S. Nucleolar organizer region activity in human chromosomes and interphase nuclei of normal, leukemic, and tumor cells as evaluated by silver staining. Int Rev Cytol 1990;121:233-66.

8 Derenzini M, Ploton D. Interphase nucleolar organizer regions in cancer cells. Int Rev Exp Pathol 1991;32:149-92.

9 Gonzalez-Guzman I. Generalities on the nucleolar content of some blood cells. Blood 1947;Suppl 2:57-65.

10 Gonzalez-Guzman I. Contribution a la connaissance de l'appareil nucléolaire des cellules leucemiques. Sang 1949; 20:225-38.

11 Mamaev NN, Mamaeva SE, Liburkina IL, Kozlova TV, Medvedeva NV, Makarkina GN. The activity of nucleolar organizer regions (NOR's) of human bone marrow cells studied with silver staining. I. Chronic myelocytic leukemia. Cancer Genet Cytogenet 1985;16:311-20.

12 Mamaev NN, Mamaeva SE, Grabovskaya IL, Makarkina GN, Kozlova TV, Medvedeva NV. The activity of nucleolar organizer regions (NOR's) of human bone marrow cells studied with silver staining. II. Acute leukemia. Cancer Genet Cytogenet 1987;25:67-72.

13 Mamaev NN, Mamaeva SE. The structure and function of nucleolar organizer regions (NORs): molecular, cytological, and clinical aspects. Tsitologiya 1992;34(10):3-25. (In Russian).

14 Mamaev NN, Grichanova TI, Shandlorenko D, Koloskov AV. Morphological and functional characteristics of normal and pathological megakaryocytes as evaluated by silver stan). 
15 Nikicicz EP, Norbach DH. Argyrophilic nucleolar organizer region (AgNOR) staining in normal bone marrow cells. $\mathscr{f}$ Clin Pathol 1990;43:723-7.

16 Arden KC, Pathak S. Various activities of the nucleolus organizer region in normal and leukemic bone marrow cells: semiquantitative data and computer assisted image analysis by silver staining. Genatol Transfuziol 1990;35(11): 4-11. (In Russian).

17 Ikonnikova OA, Lenskaia RV, Kondratchik KL, Chernov VM. Ultrastructural picture and nucleolus organizer activity of leukemic cells in children with acute lymphoblastic tivity of leukemic cells in children with acute lymphoblastic
leukemia of the "general" type. Gematol Transfuziol 1990; 35(11):11-4. (In Russian)

18 Ikonnikova OA, Lenskaia RV, Zatsepina OV, Kondratchik KL, Chernov VM. Ag-negative phenomenon of nucleolar organizers of bone marrow and blood cells in children with acute lymphoblastic leukemia. Exp Onkol 1990;12(4): 40-3. (In Russian).

19 Grotto HZW, Lorand-Metze K. Nucleolar organizer regions in normal hematopoieses: relationship to cellular proliferation and maturation. Nouv Rev Fr Hematol 1991;33: $1-4$.

20 Matolcsy A, Nador R, Weber E, Konya T. Nucleolar organizer regions of megakaryocytes in chronic myeloproliferative disorders. Virchows Arch A Pathol Anat 1992 402:441-5.

21 Ivanyi JL, Kiss A. (1992) Nucleolar organizer regions in acute and chronic leukemias. Acta Histochem (fena) 1992 93:453-61.

22 Pich A, Chiusa L, Marmont F, Capello N, Navone R. Argyrophilic nucleolar organizer region counts in multiple myeloma: a histopathological study on bone marrow trephine biopses. Virchows Arch A Pathol Anat 1992;421: phine bion.

23 Pich A, Marmont F, Chiusa L, Cappello N, Resegotti L, Navone R. Argyrophilic nucleolar organizer region counts and prognosis in multiple myeloma. Br f Haematol 1992; 82:681-8

24 Nakamura S, Takeda Y, Okabe Y, Yoshida T, Ohtake S, Kobayashi $\mathrm{K}$, et al. Argyrophilic proteins of the nucleola organizer region in acute leukemias and its relation to the S-phase fraction of leukemic cells. Acta Haematol 1992; 87:6-10.

25 Grotto HZ, Metze K, Lorand-Metze I. Pattern of nucleolar organizer regions in human leukemic cells. Anal Cell Pathol 1993;54:203-12.

26 Pich A, Chiusa L, Boccadoro M, Marmont F. AgNORs and myeloma prognosis. Leukemia Lymphoma 1994;12: 383-94.

27 Henkin A, Mamaev N. Information structures of bone marrow and blood detected with PC-based "HEMA" system (theoretical approaches and clinical practice). XIth International Meeting of the ISH, Basel, 1991:134.

28 Mamaev N, Henkin A, Gutschin V, Koloskov A, Salogub G. New approach to diagnosis, prognosis and treatment of blastic crisis of chronic myelocytic leukemia. 2nd International Conference on chronic myeloid leukemia, Bologna, 1992:183.

29 Crocker J, Hall PA, Macartney JC, Stansfeld AG. A comparative study of nucleolar organizer regions (AgNORs). parative study of nucleolar organizer regions (AgNORs). Ki67 staining and DNA flow cytometry in no
lymphomas [abstr]. $\mathcal{F}$ Pathol 1988;154:37A.

30 Derenzini M, Pession A, Trere D. The quantity of nucleolar silver-stained proteins is related to proliferating activity in cancer cells. Lab Invest 1990;63:137-40.

31 Ruschoff J, Neumann K, Contractor H, Plate K, Thomas C. Assessment of nucleolar organizer regions (NORs) by automatic image analysis in breast cancer: correlation with DNA content, proliferation rate, receptor status and histopathological grading. $\mathcal{f}$ Cancer Res Clin Oncol 1990 116:480-5.

32 Baatout S, Chatelain B, Dupret P, Staquet PH, Venkerhoven $P$, Symann $M$. Nucleolar organizer regions of megakaryocyte cell lines augment after induction of polyploidization by cytochalasin B. Exp Hematol 1993;21:1038. 33 Gavosto F. Nucleic acids and protein metabolism of bone marrow cells studied by means of ${ }^{3} \mathrm{H}$-labelled precursors. In: Proceedings of a symposium on tritium in physical In: Proceedings of a symposium on tritium in

34 Brandt L. Difference in uptake of tritiated thymidine by myelocytes from bone marrow and spleen in chronic myeloid leukemia. Scand f Haematol 1973;11:23-6.

35 Gavosto F. Granulopoiesis and cell kinetics in chronic myeloid leukemia. Cell Tissue Kinet 1974;7:151-63.

36 Baccarani M, Santucci MA, Tura S. Observations on the cytokinetics of chronic myeloid leukemia. In: Tura S, Baccarani $M$, eds. International Conference on chronic myeloid leukemia. Bologna, 1972:76.

37 Baccarani M, Killmann S-A. Cytokinetic studies in chronic myeloid leukemia: evidence for early presence of abnormal myeloid leukemia: evidence for early presence of
myeloblasts. Scand $\mathcal{F}$ Haematol 1972;9:283-92.

38 Quaqlino D, De Pasquale A, Zanni G, Zagni G. Autoradiographic and cytophotometric studies on granulocyte precursors in chronic myeloid leukemia. Haematologica 1974;59:298-315.

39 Dormer P. Kinetics of proliferation in normal hemopoietic and leukemic cells. In: Gerlach E, Moser K, Deutsch E Willmanns W, eds. Erythrocytes, thrombocytes, leukocytes. Stuttgart: Thieme Verlag, 1973:356-64.

40 Dormer P, Lau B, Wilmanns W. Kinetics of bone marrow cell production in human acute and chronic myeloid leukemias. Leukemia Res 1980;4:231-7.

41 Renner D, Queisser W. Megakaryocyte polyploidy and maturation in chronic granulocytic leukemia. Acta Haematol uration in chronic
$1988 ; 80: 74-8$

42 Banavali SD, Advani SH. A hypothetical model to explain the "termination" of chronic myeloid leukemia into blastic crisis. Med Hypotheses 1991;34:111-5.

43 Gordon MY. Cell biology of CML-a model linking the chronic and terminal phases. Leukemia Lymphoma 1993, 11:(Suppl 1): $93-100$

44 Stryckmans P, Debusscher L, Socquet M. Regulation of bone marrow myeloblasts proliferation in chronic myeloid leukemia. Cancer Res 1976;36:3034-8.

45 Gavosto F, Aglietta M. Normal and leukemic granulopoiesis. Haematologica 1981;66:1-9.

46 Ernst P, Baccarani M, Killmann SA. Biochemical abnormality of DNA synthesis of erythroblasts in acute and chronic myeloid leukemia. Blood 1973;41:497-504.

47 Kanayev SV, Vashkinel VK, Dotsenko MS, Nad GK, Petrov MN, Lapchenkov VI, Phyedorov VV. Functional and structural changes in the cells of erythroid lineage and in platelets from patients with leukemia. Hematol Transfusiol Probl 1975;20(3):18-24. (In Russian)

48 Thile J, Hoefer M, Kvasnicka HM, Bertsch HP, Zankovich $R$, Fischer $R$. Erythropoiesis in CML-immunomorphometric quantification, PCNA-reactivity, and inmorphometric quantification, PCNA-reactivity, and
fluence on survival. Hematol Pathol 1993;7:239-49.

49 Strife A, Perez A, Lambek C, Wisniewski D, Bruno S Darzynkiewicz Z, et al. Difference in the composition and in the efficiency of red cell production of normal and CML erythroid progenitor populations are highlighted by response to human c-kit ligand. Leukemia Res 1993;17 799-807. 